\title{
Weathering Performance of Beech Wood Coated with Acrylic Paint Containing UV Stabilizers of Dihydroxy Benzophenone and Nano Zinc Oxide
}

\section{Svojstva bukovine obrađene akrilnim premazom koji sadržava UV stabilizatore dihidroksi-benzofenon i nano cinkov oksid nakon izlaganja vremenskim utjecajima}

Preliminary paper • Prethodno priopćenje

Received-prispjelo: 21. 2. 2019.

Accepted-prihvaćeno: 15. 7. 2020.

UDK: $630 * 814.11 ; 630 * 829.2$

https://doi.org/10.5552/drvind.2020.1912

(C) 2020 by the author(s) Licensee Faculty of Forestry, University of Zagreb. This article is an open access article distributed under the terms and conditions of the Creative Commons Attribution (CC BY 4.0) license.

\begin{abstract}
In this study, the effect of UV stabilizers (dihydroxy benzophenone and nano zinc oxide) on the weathering degradation of water-based acrylic coating on beech wood was investigated. The wood specimens were coated by brush and then weathered naturally for six months. The obtained results showed that the use of nano zinc oxide reduced color changes and mold growth on the surface of weathered samples. However, the results of contact angle, pull-off adhesion, colorimeter and FTIR revealed that the dihydroxyl benzophenone was not effective in preventing weathering degradation of coated wood.
\end{abstract}

Keywords: acrylic coating; weathering; beech wood; dihydroxy benzophenone and nano zinc oxide

SAŽETAK • U radu se prikazuje istraživanje utjecaja UV stabilizatora (dihidroksi-benzofenona $i$ nano cinkova oksida) na razgradnju vodenoga akrilnog premaza na bukovini koja je bila izložena vremenskim utjecajima. Uzorci drva premazani su kistom, a potom su šest mjeseci prirodno izloženi vremenskim utjecajima. Dobiveni su rezultati pokazali da nano cinkov oksid smanjuje promjenu boje i pojavu plijesni na površini izloženih uzoraka. Međutim, rezultati kontaktnog kuta, adhezije, kolorimetrije i FTIR analize potvrđuju da dihidroksi-benzofenon nije učinkovit u sprečavanju razgradnje premazanog drva.

Ključne riječi: akrilni premaz; izlaganje vremenskim utjecajima; bukovina; dihidroksi-benzofenon; nano cinkov oksid

\footnotetext{
${ }^{1}$ Authors are researchers at Gorgan University of Agricultural Sciences, Gorgan University of Agricultural Sciences and Natural Resources, Department of Wood Engineering and Technology, Gorgan, Iran.
} 


\section{INTRODUCTION}

\section{UVOD}

Wood possesses several attractive properties, such as aesthetic appeal, low density and mechanical strength, making it one of the most widely used materials for engineering and structural application. Unfortunately, when wood is exposed outdoor, a variety of weathering factors degrade the main wood components (Macleod et al., 1995). The factors contributing most to wood degradation by weathering are UV radiation and water; thereby, mainly lignin is decomposed to lowermolecular-weight compounds, which are washed out by rain. Since the penetration of UV waves is superficial, weathering affects the aesthetic properties of wood more than the mechanical ones (Feist, 1982). The change of wood color is the first sign of photo degradation when wood is exposed to UV radiation. Undesirable changes, such as discoloration, roughness and cracks, are observed when wood is further exposed to environmental conditions, such as heat, water and microorganisms (Turkoglu et al., 2015, Temiz et al., 2007). Different approaches are pursued to protect wood from weathering degradation, whereas the common method is the application of coatings (Bulian and Graystone, 2009; Chang and Chou, 2000). Clear coating is one of the desirable and effective methods, which protects the wood surface keeping the wood grain and color visible, with no negative effect on the wood natural appearance. Water based acrylic polyurethane - as one of the common clear coatings - is durable, highly efficient, non-toxic, and widely applied in the recent years due to growing environmental concerns (Saha et al., 2011). For outdoor applications, incorporation of organic and inorganic UV absorbers and hindered amine light stabilizers (HALS) is necessary due to the development of transparent coatings. These compounds are used for the retardation and elimination of photochemical processes in polymers (Malanowski, 2009). The mechanism of stabilizing organic UV absorbers involves absorption of UV light and a subsequent quick dissipation of absorbed energy in the form of harmless long-wavelength radiation. Derivatives of hydroxyl phenyl benzotriazole, hydroxyl phenyl benzophenone and hydroxyl phenyl-s-triazines are applied as organic UV absorbers. Inorganic UV absorbers protect a polymer by reflecting the harmful UV light. Among the inorganic UV absorbers, zinc oxide has a long history of color protection. It has the advantage of a higher photo permanence compared to organic stabilizers (Saha et al., 2011; Wang and Tooley, 2011). Furthermore, its effectiveness in blocking UV radiation boosted in nanosized when compared to bulk. However, nanoparticles tend to agglomerate due to their large surface area and high surface energy. The formation of agglomerates reduces the UV absorbing capacity and, therefore, the UV shielding properties of these nanoparticles (Becheri et al., 2008). They have to be re-dispersed, most effectively by ultra-sonication, and stabilized to prevent a new agglomeration (Fufa et al., 2012). Some studies have shown that the use of zinc oxide
$(\mathrm{ZnO})$ as a UV absorber in coatings improves weathering performance of coated wood samples. Weichelt et al. (2011) studied the efficiency of ZnO-based acrylate coatings on wood during artificial weathering. Their results show that nano-ZnO acts as a UV absorber by reducing yellowing and improving optical properties. Salla et al. (2012) mentioned that the incorporation of $\mathrm{ZnO}$ nanoparticles in PU coatings enhanced the photostability of coated rubber wood during weathering.

This study aimed to compare the efficiency of dihydroxy benzophenone and $\mathrm{ZnO}$ nanoparticles against weathering of coated wood. To approach this purpose, the modified water based acrylic coating was applied on beech wood surface and then the treated wood specimens were exposed to natural weathering.

\section{MATERIALS AND METHODS}

\section{MATERIJALI I METODE}

Defect-free beech (Fagus orientalis L.) wood specimens $(12 \mathrm{~cm} \times 10 \mathrm{~cm} \times 1 \mathrm{~cm}$; $\mathrm{L} \times \mathrm{T} \times \mathrm{R})$ were cut from air dried boards and then sanded using P220 sandpaper. The transparent water-based acrylic (methyl methacrylate-styrene copolymer) with $42 \mathrm{wt} \%$ solid content was obtained from Newcolour/Iran. Nano-sized $\mathrm{ZnO}$ particles (average size of $60 \mathrm{~nm}$ ) and 2, 4 -dihydroxy benzophenone as UV stabilizers were provided by Alfa Aesar/USA and Sigma Alderich/ Germany, respectively. In this study, raw wood as a control sample (CS) unmodified (UN), modified with $0.5 \mathrm{wt} \%$ of dihydroxy benzophenone (UA) and $0.5 \mathrm{wt} \%$ of $\mathrm{ZnO}$ nano particles (ZN) coatings were applied on wooden surfaces by brush and allowed to dry for 48 hours. There was only one coating layer and its quantity was adjusted to approximately $120 \mathrm{~g} / \mathrm{m}^{2}$ for all samples. To modify the coating with dihydroxy benzophenone, it (0.42 g) was dissolved in ethanol $(10 \mathrm{ml})$ and then mixed with an acrylic coating (200 g) using a magnetic stirrer for 15 min. To modify the coating with $\mathrm{ZnO}$ nanoparticles, 10 $\mathrm{g}$ of $\mathrm{ZnO}$ nanoparticles was suspended in distilled water $(190 \mathrm{~g})$ using sonication for $30 \mathrm{~min}$. The suspensions ( $8.4 \mathrm{~g}$ ) were then added to the coating ( $200 \mathrm{~g}$ ) and mixed using a magnetic stirrer for $15 \mathrm{~min}$.

\subsection{Natural weathering}

2.1. Prirodno izlaganje vremenskim utjecajima

The weatherability of wood specimens finished with modified coatings was assessed using natural weathering. In order to approach this purpose, the specimens were exposed outdoors facing south at an angle of $45^{\circ}$ to the horizontal in Gorgan, Iran from March to September 2017.

\subsection{Field emission scanning electron microscope (FE-SEM)}

2.2. Pretražni elektronski mikroskop s emisijom polja (FE-SEM)

To observe and confirm the nano-scale size and morphology of $\mathrm{ZnO}$ nanoparticles, a FE-SEM (MRA3, TESCAN Co.) operating at voltage of $10 \mathrm{kV}$ was used. The diameter of $100 \mathrm{ZnO}$ nanoparticles was measured using DigiMizer software. 
Table 1 Average weather conditions in Gorgan from March to September 2017

Tablica 1. Prosječne vrijednosti vremenskih uvjeta za Gorgan od ožujka do rujna 2017.

\begin{tabular}{|c|c|c|c|c|c|c|c|}
\hline $\begin{array}{c}\text { Daily } \\
\text { tempera- } \\
\text { ture, }{ }^{\circ} \mathrm{C} \\
\text { Dnevna } \\
\text { temperatura, } \\
{ }^{\circ} \mathrm{C}\end{array}$ & $\begin{array}{c}\text { Daily mini- } \\
\text { mum tem- } \\
\text { perature, }{ }^{\circ} \mathbf{C} \\
\text { Najniža dnevna } \\
\text { temperatura, } \\
{ }^{\circ} \mathrm{C}\end{array}$ & $\begin{array}{c}\text { Daily maxi- } \\
\text { mum tempera- } \\
\text { ture, }{ }^{\circ} \mathbf{C} \\
\text { Najviša dnevna } \\
\text { temperatura, } \\
{ }^{\circ} \mathrm{C}\end{array}$ & $\begin{array}{c}\text { Daily relative } \\
\text { humidity, \% } \\
\text { Dnevna } \\
\text { relativna } \\
\text { vlažnost } \\
\text { zraka, \% }\end{array}$ & $\begin{array}{l}\text { Daily minimum } \\
\text { relative } \\
\text { humidity, \% } \\
\text { Najmanja } \\
\text { dnevna relativna } \\
\text { vlažnost zraka, } \\
\% \\
\end{array}$ & $\begin{array}{c}\text { Daily maxi- } \\
\text { mum relative } \\
\text { humidity, \% } \\
\text { Najveća dnevna } \\
\text { relativna } \\
\text { vlažnost zraka, } \\
\%\end{array}$ & $\begin{array}{c}\text { Monthly } \\
\text { rainfall, } \\
\text { mm } \\
\text { Mjesečne } \\
\text { padaline, } \\
\text { mm }\end{array}$ & $\begin{array}{c}\text { Monthly } \\
\text { hours of } \\
\text { sunshine, } \\
\text { hrs } \\
\text { Sunčani } \\
\text { sati } u \\
\text { mjesecu, h }\end{array}$ \\
\hline 21.16 & & 35.6 & 66.63 & 26.8 & 93.8 & 19.1 & 273.3 \\
\hline
\end{tabular}

\subsection{Adhesion test}

2.3. Ispitivanje adhezije

The pull-off method was used to evaluate adhesion strength between the wood and coating. All measurements were carried out with a Positest pull-off Adhesion Tester (DeFelsko, USA) based on ASTM D4541. The aluminum dollies of $20 \mathrm{~mm}$ diameter were glued onto the surface of the coated wood with an epoxy resin (UHU Plus, Germany) and allowed to cure for $24 \mathrm{hrs}$ at room conditions. Then, a slot was cut into the coating film around the dollies. Finally, a dolly was separated by applying a force perpendicular to the surface test.

\subsection{Color measurement}

2.4. Mjerenje boje

The colors of specimens in $L^{*} a^{*} b^{*}$ coordinates were measured using a colorimeter (Lovi bond S500, USA) according to ASTM D2244. The color difference $\left(\Delta E^{*}\right)$ was determined for each sample by calculating from initial and final values using the following equation (Eq. 1):

$$
\Delta E^{*}=\sqrt{\Delta L^{* 2}+\Delta a^{* 2}+\Delta b^{* 2}}
$$

where $\Delta a^{*}, \Delta b^{*}$ and $\Delta L^{*}$ are the changes between the initial and final interval values.

\subsection{Contact angle tests}

2.5. Ispitivanje kontaktnog kuta

The contact angle tests were performed using PG-X Measuring Head (Switzerland) according to ASTM D5946 and were measured by a droplet of deionized water $(3 \mu \mathrm{l})$. In this study, the contact angles of the sample surface were determined before and after weathering from zero to 10 seconds and were repeated with five drops for each sample.

\subsection{ATR-FTIR analysis}

\subsection{ATR-FTIR analiza}

ATR-FTIR spectroscopy (Vertex 80 spectrometer, Bruker Optics, Germany) was applied to study coated samples during weathering. For all samples, band intensities were normalized using the band at $1450 \mathrm{~cm}^{-1}$, which exhibited a negligible change during weathering (Forsthuber et al., 2013).

\subsection{Stereomicroscope analysis \\ 2.7. Analiza stereomikroskopom}

Stereomicroscope (Olympus, Japan) was used to investigate the surface morphology of coated wood specimens during weathering.

\section{RESULTS AND DISCUSSION 3. REZULTATI I RASPRAVA}

Figure 1 shows the FE-SEM of $\mathrm{ZN}$, confirming all ZNs were in the range of nanoscale size and had almost uniform size. The average diameter of $\mathrm{ZN}$ obtained was $55 \pm 16 \mathrm{~nm}$.

\subsection{Adhesion strength}

3.1. Adhezivna čvrstoća

The adhesion strength of acrylic paint, as indicated by force used to separate glued dolly from the surface test, is shown in Figure 2 for weathered and

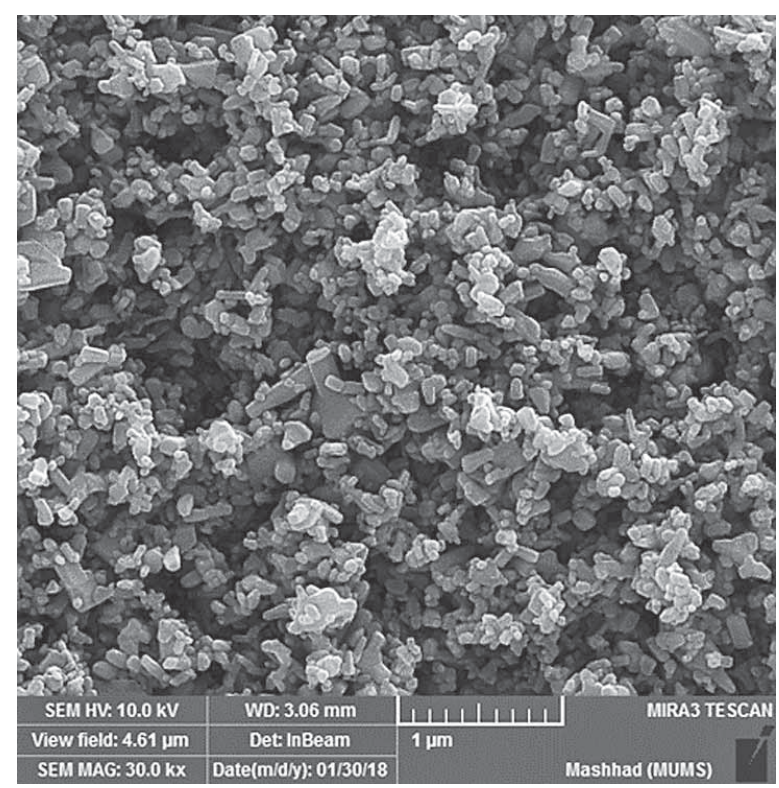

Figure 1 FESEM of $\mathrm{ZnO}$ particles

Slika 1. FESEM ZnO čestica

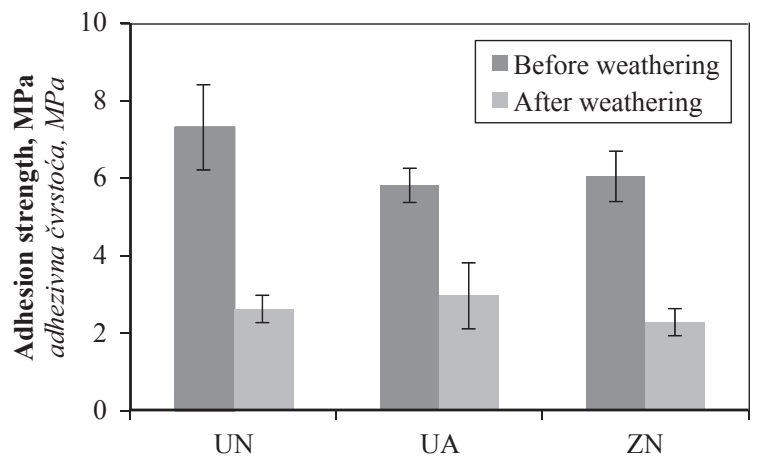

Figure 2 Adhesion strength of samples before and after weathering

Slika 2. Adhezivna čvrstoća uzoraka prije i nakon izlaganja vremenskim utjecajima 


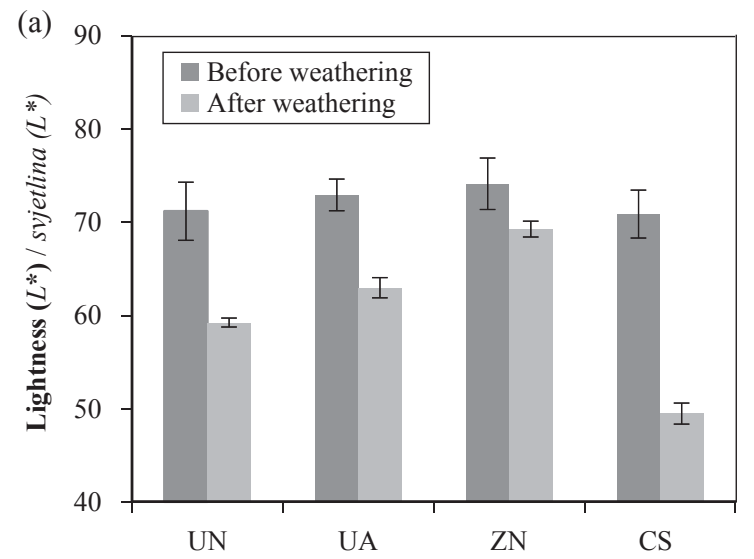

(c)

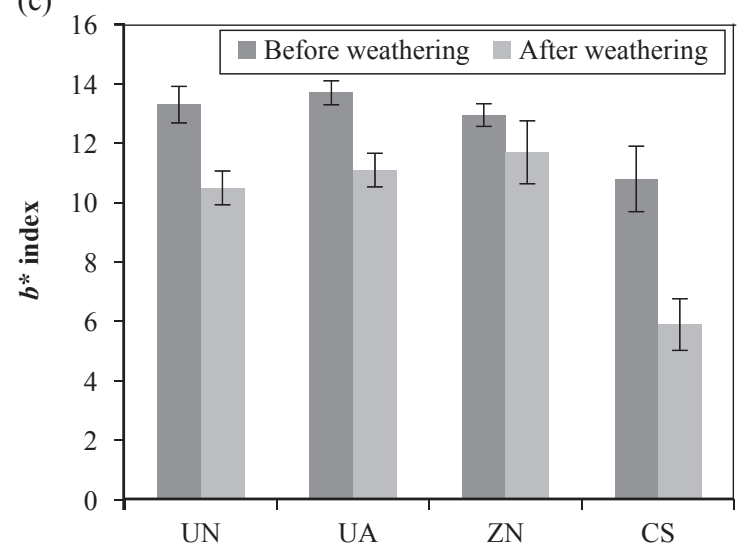

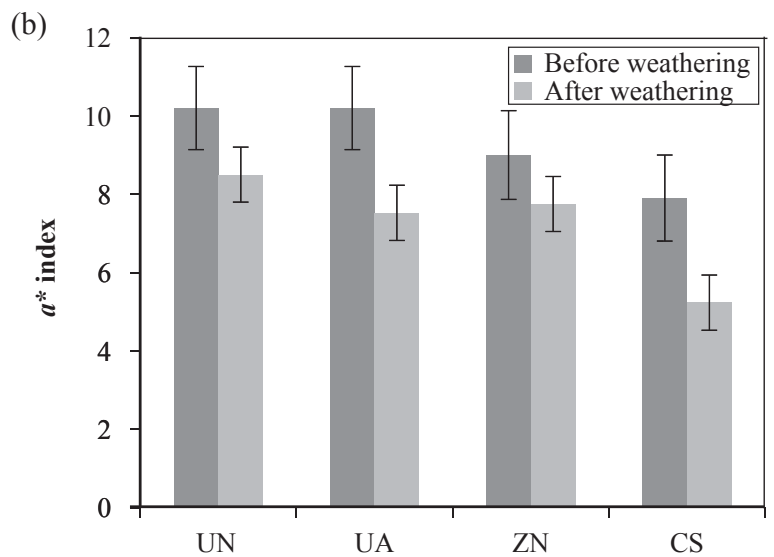

(d)

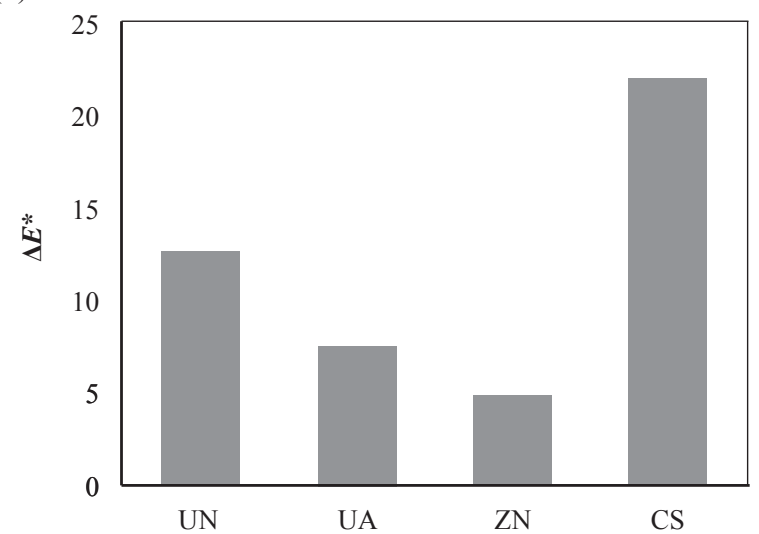

Figure 3 Comparison of acrylic coatings stabilized with different additives: lightness (a), red-green index (b), yellow-blue index (c) and total color change (d) (Error bar shows standard deviation)

Slika 3. Usporedba akrilnih premaza stabiliziranih različitim aditivima: svjetlina (a), crveno-zeleni indeks (b), žuto-plavi indeks (c) i ukupna promjena boje (d) (traka pogreške prikazuje standardnu devijaciju)

unweathered specimens. In unweathered cases, unmodified coating (UN) showed the highest value, while modified coating containing $\mathrm{ZnO}$ and dihydroxy benzophenone (ZN and UA) showed a reduction in adhesion strength. This reduction has been previously reported in the presence of nano $\mathrm{ZnO}$ (Miklečić et al., 2017). Unfortunately, $\mathrm{ZnO}$ nanoparticles exhibit a high tendency to agglomerate in the polymer matrix because of its large surface area and high surface energy (Kathalewar et al., 2013). The results obviously revealed that six months of outdoor conditions significantly reduced the adhesion of coating. The loss of adhesion was previously reported for wood transparent coating during weathering (Singh and Dawson, 2003). Solar radiation penetrated through transparent coating on the surface of wood and degraded underlying wood, causing failure between wood and paint. These results confirmed that the coating modified with dihydroxy benzophenone and $\mathrm{ZnO}$ was more effective in reducing adhesion loss of applied coatings during weathering than unmodified coatings. It is interesting to note that the dominant failure types in the pull-off test were the adhesive failures between wood and coating.

\subsection{Color measurement}

\subsection{Mjerenje boje}

The results of color indexes $\left(L^{*}, a^{*}, b^{*}\right)$ and color differences before and after six months of weathering are presented in Figure 3a. The results show that the weathering process was effective on lightness $\left(L^{*}\right)$ in such a way that all samples became darker than those unweathered. The majority of UV is absorbed by lignin in wood and its photooxidation causes the formation of yellow to brownish compounds (ortho and para quinonoid compounds), resulting in the initial dark-brown color of wood during weathering. Additionally, the mold or mildew growth on the wood or coating surfaces usually appears as black spots during weathering (Nejad and Cooper, 2017). The highest change of $L^{*}$ was observed in the case of $\mathrm{UN}$ and the lowest with $\mathrm{ZN}$. For all

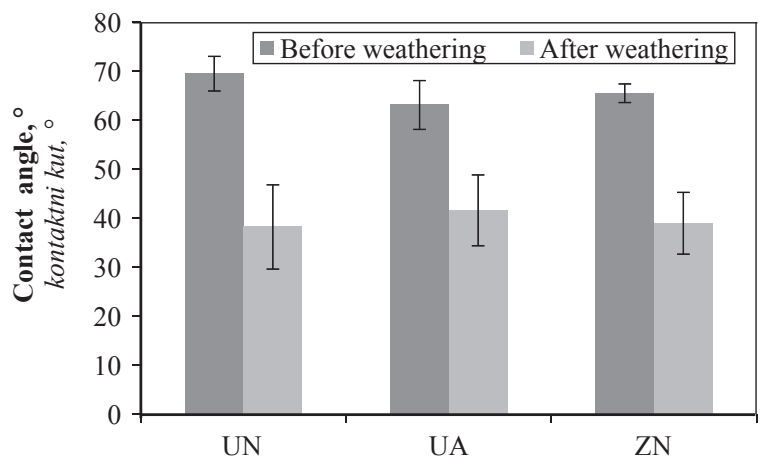

Figure 4 Contact angle diagram for different UV absorbents before and after weathering (Error bar shows standard deviation)

Slika 4. Prikaz kontaktnog kuta za različite UV apsorbere prije i nakon izlaganja vremenskim utjecajima (traka pogreške prikazuje standardnu devijaciju) 


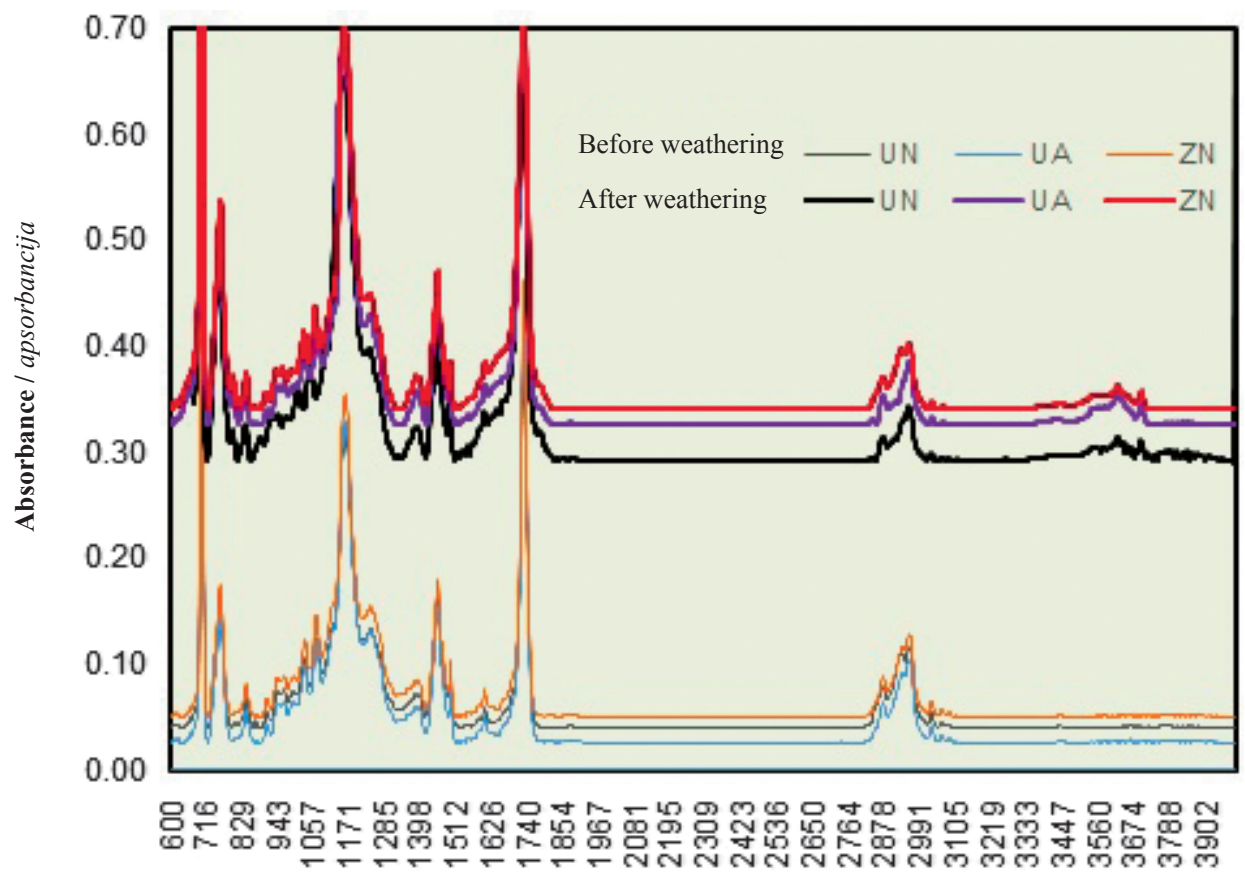

Wavenumber, $\mathbf{c m}^{-1} /$ valni broj, $\mathrm{cm}^{-1}$

Figure 5 Infrared spectra of coated samples containing different UV absorbents before and after natural weathering Slika 5. Infracrveni spektar premazanih uzoraka koji sadržavaju različite UV apsorbere prije i nakon izlaganja vremenskim utjecajima

$\mathrm{UN}$
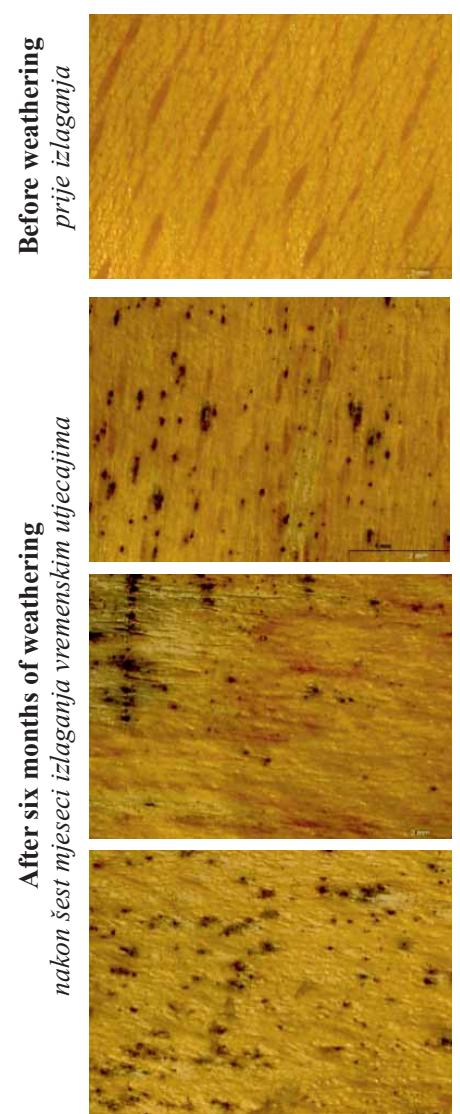

UA
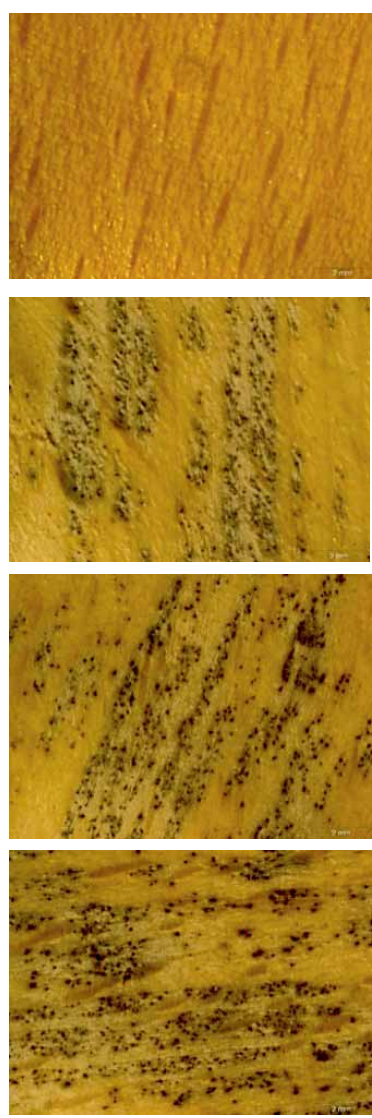

ZN
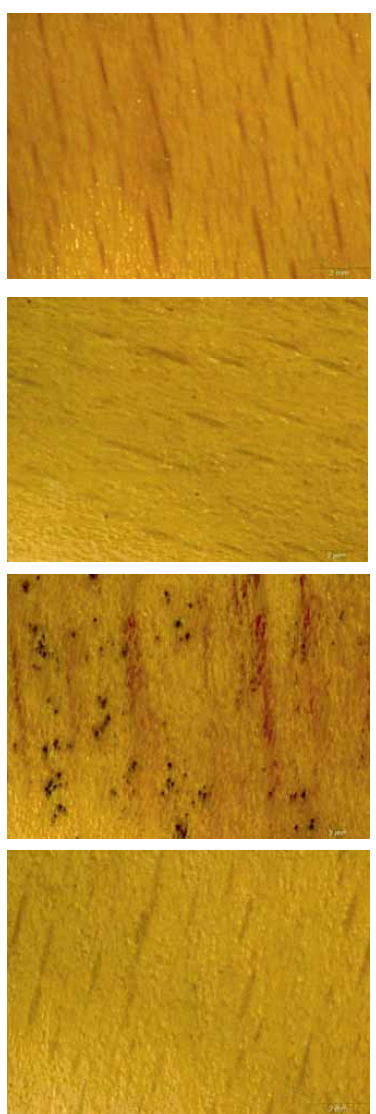

CS
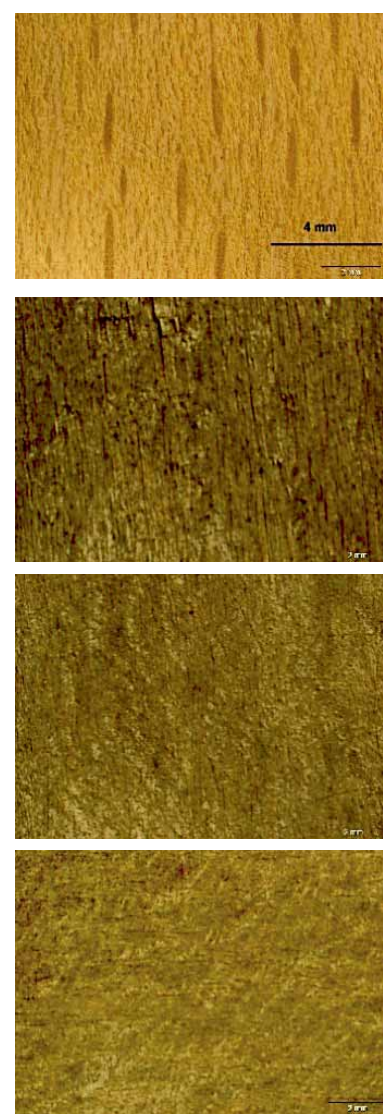

Figure 6 Visual assessments of uncoated and coated beech surface before (one replicate) and after weathering (tree replicates)

Slika 6. Vizualna ocjena nepremazane i premazane površine bukovine prije (jedan uzorak) i nakon izlaganja vremenskim utjecajima (tri uzorka) 
coated specimens, $a^{*}$ and $b^{*}$ indexes were almost equally reduced after weathering (Figure $3 b$ and $3 c$ ). The overall color changes $\left(\Delta E^{*}\right)$ after six-month natural weathering are presented in Figure 3d. For uncoated wooden samples, the color change was 22.08, which was higher than that of the coated samples. This finding shows that the application of acrylic coating was effective to avoid weathering degradation. Furthermore, modifying coating with $\mathrm{ZnO}$ had a positive impact on the color stability of wooden samples during weathering. Miklečić et al. concluded that the addition of $\mathrm{ZnO}$ nanoparticles into the polyacrylate coating resulted in higher color stability of thermally modified beech wood samples during natural weathering. The weathering is usually accompanied by the growth of dark-colored spores of mold fungi on the wood surface, which causes more color changes in the appearance (Tracton, 2006). The reduction of color changes due to the use of $\mathrm{ZnO}$ is related to fungicide properties of this material that is evident in stereo microscopic images.

\subsection{Contact angles}

\subsection{Kontaktni kutovi}

The surface hydrophilicity of the samples was determined by contact angle measurement (Figure 4). The results showed that the surface hydrophilicity increased after weathering, where it was extreme for uncoated samples. An increased wettability of weathered samples is related to changes in the surface chemical compositions and the increase of surface roughness caused by cracks (Matuana and Kamdem, 2002; Meiron et al., 2004). According to Figure 4, the modification of coating was not effective on the decreasing of contact angle changes of samples during weathering.

\subsection{ATR-FTIR}

3.4. ATR-FTIR

ATR-FTIR experiments were performed to study the chemical degradation of the coatings before and after weathering (Figure 5). The main changes are related to a wide band in the region $3500-3700 \mathrm{~cm}^{-1}$. This band belongs to the stretching vibration of hydroxyl of water absorbed in the coating during the weathering process. Furthermore, there are no noticeable changes in intensity peaks around $1730,2960,1150$ and 880 $\mathrm{cm}^{-1}$, where the signs of oxidation degradation due to weathering could be expected (Allen et al., 1997; Nguyen et al., 2016). This revealed that during sixmonth natural weathering, all coatings were resistant to photooxidation.

\subsection{Stereomicroscope analysis
3.5. Analiza stereomikroskopom}

Visual assessments of the uncoated and coated beech were evaluated by stereomicroscope (Figure 6). In uncoated samples, mold growth caused disfigurement of weathered samples. In addition to abiotic factors (sunlight, metal ion, etc.), biotic factors (molds, fungi, etc.) affect the color changes during natural weathering (Mohebby and Saei, 2015). Mold fungi can also grow on the painted wood and penetrate into the paint film, thereby colonizing in the interface between wood and paint (Gobakken and Westin, 2008). Aureobasidium pullulans is the most common mold observed on weathered wood (Rowell, 2012). It is very resistant to stress factors. It can withstand temperatures up to $80{ }^{\circ} \mathrm{C}$ and $\mathrm{pH}$ range from $1.9-10.1$ and survive for a long time without moisture (Kutz, 2005). So, the use of the proper additive is necessary for the paint structure in outdoor applications. The images of stereomicroscope revealed that hydroxy benzophenone, as UV stabilizer, could not prevent the expansion and growth of mold, while $\mathrm{ZN}$, due to antifungal properties, was effective against mold growth. These results correspond to the report of Terzi et al. (2016).

\section{CONCLUSIONS}

4. ZAKLJUČAK

The modification of acrylic paint with 2, 4 -dihydroxy benzophenone revealed that it had no effect against natural weathering, evidenced by observing adhesion strength, color and contact angle changes. During weathering, $\mathrm{ZnO}$ nanoparticles reduced the color changes and mold growth on coated wood samples by absorbing a wide range of UV radiation.

\section{REFERENCES}

\section{LITERATURA}

1. Allen, N.; Regan, C.; Mcintyre, R.; Johnson, B.; Dunk, W., 1997: The photooxidation and stabilisation of water-borne acrylic emulsions. Progress in Organic Coatings, 32: 9-16. https://doi.org/10.1016/s0300-9440(97)00065-9.

2. Becheri, A.; Dürr, M.; Nostro, P. L.; Baglioni, P., 2008: Synthesis and characterization of zinc oxide nanoparticles: application to textiles as UV-absorbers. Journal of Nanoparticle Research, 10: 679-689. https://doi.org/10.1007/s11051-007-9318-3.

3. Bulian, F.; Graystone, J., 2009: Industrial Wood Coatings. Theory and practice, Eiselvier BU Amsterdam Oxford, 33-37.

4. Chang, S.-T.; Chou, P.-L., 2000: Photodiscoloration inhibition of wood coated with UV-curable acrylic clear coatings and its elucidation. Polymer degradation and stability, 69: 355-360. https://doi.org/10.1016/s0141-3910(00)00082-3.

5. Feist, W. C., 1982: Weathering of wood in structural uses. USDA Forest Service, Forest Products Laboratory.

6. Forsthuber, B.; Müller, U.; Teischinger, A.; Grüll, G., 2013: Chemical and mechanical changes during photooxidation of an acrylic clear wood coat and its prevention using UV absorber and micronized $\mathrm{TiO}_{2}$. Polymer degradation and stability, 98: 1329-1338. https://doi.org/10.1016/j.polymdegradstab.2013.03.029.

7. Fufa, S. M.; Jelle, B. P.; Hovde, P. J.; Rørvik, P. M., 2012: Coated wooden claddings and the influence of nanoparticles on the weathering performance. Progress in Organic Coatings, 75: 72-78.

ttps://doi.org/10.1016/j.porgcoat.2012.03.010.

8. Gobakken, L. R.; Westin, M., 2008: Surface mould growth on five modified wood substrates coated with three different coating systems when exposed outdoors. 
International Biodeterioration \& Biodegradation, 62: 397-402. https://doi.org/10.1016/j.ibiod.2008.03.004.

9. Kathalewar, M.; Sabnis, A.; Waghoo, G., 2013: Effect of incorporation of surface treated zinc oxide on non-isocyanate polyurethane based nano-composite coatings. Progress in Organic Coatings, 76: 1215-1229. https://doi.org/10.1016/j.porgcoat.2013.03.027.

10. Kutz, M., 2005: Handbook of environmental degradation of materials. William Andrew.

11. Macleod, I.; Scully, A.; Ghiggino, K.; Ritchie, P.; Paravagna, O.; Leary, B., 1995: Photodegradation at the wood-clearcoat interface. Wood Science and Technology, 29: 183-189. https://doi.org/10.1007/bf00204584.

12. Malanowski, P., 2009: Weathering of aromatic polyester coatings. University of Technology.

13. Matuana, L. M.; Kamdem, D. P., 2002: Accelerated ultraviolet weathering of PVC/wood-flour composites. Polymer Engineering \& Science, 42: 1657-1666. https://doi. org/10.1002/pen.11060.

14. Meiron, T. S.; Marmur, A.; Saguy, I. S., 2004: Contact angle measurement on rough surfaces. Journal of Colloid and Interface Science, 274: 637-644.

15. Miklečić, J.; Turkulin, H.; Jirouš-Rajković, V., 2017: Weathering performance of surface of thermally modified wood finished with nanoparticles-modified waterborne polyacrylate coatings. Applied Surface Science, 408: 103-109. https://doi.org/10.1016/j.apsusc.2017.03.011.

16. Mohebby, B.; Saei, A. M., 2015: Effects of geographical directions and climatological parameters on natural weathering of fir wood. Construction and Building Materials, 94: 684-690.

https://doi.org/10.1016/j.conbuildmat.2015.07.049.

17. Nejad, M.; Cooper, P., 2017: Exterior wood coatings. Wood in Civil Engineering.

18. Nguyen, T. V.; Tri, P. N.; Nguyen, T. D.; El Aidani, R.; Trinh, V. T.; Decker, C., 2016: Accelerated degradation of water borne acrylic nanocomposites used in outdoor protective coatings. Polymer Degradation and Stability, 128: 65-76.

https://doi.org/10.1016/j.polymdegradstab.2016.03.002.

19. Rowell, R. M., 2012: Handbook of wood chemistry and wood composites. CRC press.

20. Saha, S.; Kocaefe, D.; Krause, C.; Larouche, T., 2011: Effect Of titania and zinc oxide particles on acrylic polyurethane coating performance. Progress in Organic Coatings, 70: 170-177. https://doi.org/10.1016/j.porgcoat.2010.09.021.

21. Salla, J.; Pandey, K. K.; Srinivas, K., 2012: Improvement of UV resistance of wood surfaces by using $\mathrm{ZnO}$ nanoparticles. Polymer Degradation and Stability, 97: 592596.

https://doi.org/10.1016/j.polymdegradstab.2012.01.013.
22. Singh, A. P.; Dawson, B. S., 2003: The mechanism of failure of clear coated wooden boards as revealed by microscopy. IAWA Journal, 24: 1-11. https://doi.org/10.1163/22941932-90000316.

23. Temiz, A.; Terziev, N.; Eikenes, M.; Hafren, J., 2007: Effect of accelerated weathering on surface chemistry of modified wood. Applied Surface Science, 253: 53555362. https://doi.org/10.1016/j.apsusc.2006.12.005.

24. Terzi, E.; Kartal, S. N.; Y1lgör, N.; Rautkari, L.; Yoshimura, T., 2016: Role of various nano-particles in prevention of fungal decay, mold growth and termite attack in wood, and their effect on weathering properties and water repellency. International Biodeterioration \& Biodegradation, 107: 77-87. https://doi.org/10.1016/j.ibiod.2015.11.010.

25. Tracton, A. A., 2006: Coatings materials and surface coatings. CRC Press.

26. Turkoglu, T.; Baysal, E.; Toker, H., 2015: The effects of natural weathering on color stability of impregnated and varnished wood materials. Advances in Materials Science and Engineering, ID 526570. https://doi.org/10.1155/2015/526570.

27. Wang, S. Q.; Tooley, I. R., 2011: Photoprotection in the Era of Nanotechnology. Seminars in cutaneous medicine and surgery, 210-213.

28. Weichelt, F.; Beyer, M.; Emmler, R.; Flyunt, R.; Beyer, E.; Buchmeiser, M., 2011: Zinc Oxide Based Coatings for the UV-Protection of Wood for Outdoor Applications. Macromolecular Symposia, 301: 23-30. https://doi.org/10.1002/masy.201150304.

29. ***ASTM D4541, 2010: Standard test method for pulloff strength of coatings using portable adhesion testers. Adhesives. American Society for Testing and Materials.

30. ***ASTM D2244: Standard Test Method for Calculation of Color Differences from Instrumentally Measured Color Coordinates. Aluminum Sun Shade, 10: 13-23.

31. ***ASTM D5946, 2009: Standard test method for corona-treated polymer films using water contact angle measurements. ASTM International West Conshohocken (PA).

\section{Corresponding address:}

\section{DAVOOD RASOULI}

Gorgan University of Agricultural Sciences

Gorgan University of Agricultural Sciences and Natural Resources

Department of Wood Engineering and Technology

4913815739, Gorgan, IRAN

e-mail: rasouli@gau.ac.ir 